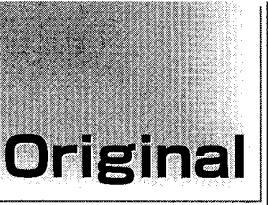

Received Dec. 6,2004

Revision accepted Oct. 28, 2005

Code No. 854

\section{Charged Particle Equilibrium of Small Field in Clinical Proton Beams}

\author{
HIROKI OHTANI
}

Tokyo Metropolitan University, Faculty of Health Sciences, School of Radiologic Science

\section{Introduction}

In the National Institute of Radiological Sciences (NIRS, Japan), clinical trials of proton beam treatment began in 1979 , using a spot scanning system. ${ }^{1,2)}$ The proton beam has special characteristics in its dose distributions as compared with ordinary broad photon beams. $^{3,4)}$

The proton beam in this study was used for the treatment of malignant melanoma of the bulbus. It was treated with about $2 \mathrm{~cm}$ of field diameter by the bulbus depth. Small field sizes of a $70 \mathrm{MeV}$ proton beam are used. Therefore, lateral charged particle equilibrium must be accurately determined, and dose evaluation at shallow depth is important. ${ }^{4-6)}$ When charged particle equilibrium is not done clearly, there is a possibility that the irradiation dose necessary for radiotherapy will be too small. As a method to estimate charged particle equilibrium, and the applicability to proton beam was tried using electron disequilibrium factor used to photon.

The dose due to primary protons, disregarding secondary charged particles generated from the tissue, ${ }^{7)}$ and secondary protons and electrons, is here called the primary equilibrium charged particle, $P_{e q}$. In situations of charged particle disequilibrium, the actual charged particle due to primary protons, $P$, drops below $P_{\text {eq }}$, and the charged particle equilibrium factor can be introduced as $\mathrm{E}(Z, R)$-factor $=P / P_{e q}{ }^{4}{ }^{4} \mathrm{E}(Z, R)$-factor is dependent on depth, $Z$, and field radius, $R$; such that $\mathrm{E}(Z, R)=\mathrm{E}(Z)$ $\mathrm{E}(R)$. It was divisible into depth direction(longitudinal component) and field direction (lateral component), and the $\mathrm{E}(Z, R)$-factor was measured. This separation was carried out by analyzing the measure.

The purpose of this study was to clearly demonstrate the relation between proton beam quality, which, for instance, can express the influence of the ridge filter and the range shifter, and secondary charged particles through

\title{
Summary
}

It is expected that proton beam radiotherapy will become an effective treatment for tumors. For an organ for which a correct dose prescription is required, a proton beam has the ability to provide the dose most suitable for the specific purpose. We measured the charged particle equilibrium factor of proton beams in water using a plane parallel ionization chamber. The maximum energy of the proton beam used in this study was $70 \mathrm{MeV}$, produced from an isochronous cyclotron. We assume that the charged particle equilibrium factor can be separated into longitudinal and lateral components, that is, the factor $\mathrm{E}(Z, R)$ is dependent on depth, $Z$, and field radius, $R$; such that $\mathrm{E}(Z, R)=\mathrm{E}(Z) \mathrm{E}(R)$. The $\mathrm{E}(Z)$-factor of primary protons was considered in order to investigate the influence of secondary charged particles. From the results, the charged particle equilibrium factor for the longitudinal component does not remain sharp with the decrease of water depth, and the lateral component is not maintained with the decrease of field size. However, the longitudinal components of primary protons at shallow depth were in equilibrium.

Key words: Proton beam radiotherapy, Dosimetry, Dose distribution, Charged particle equilibrium, Small field 
the measurement of the $\mathrm{E}(Z, R)$-factor in terms of primary protons and secondary charged particles.

\section{Materials and Methods}

\section{1-1 Characteristics of proton equipment}

Figure 1 shows a drawing of the proton delivery equipment used in this experiment. To be useful for radiation therapy, a proton beam has to be expanded into the lateral and the depth directions. Therefore, the wobbler magnets in vertical and horizontal directions are made up of twin induction coils.

The range shifter is made of aluminum (density, $\left.2.69 \mathrm{~g} / \mathrm{cm}^{3}\right)$. The thickness of the range shifter can be changed from the tail of the Bragg peak to the local distal edge of the target with a maximum thickness of $16 \mathrm{~mm}$.

The proton beams that are generated are spread to a size sufficient to cover the tumor. ${ }^{8)}$ Two sizes of ridge filter are used, $15 \mathrm{~mm}$ (acrylic) and $30 \mathrm{~mm}$ (aluminum). The spread-out Bragg peak (SOBP) of proton beams is achieved by introducing different thicknesses of the ridge filter in its path before it penetrates the patient.

Measurement of the SOBP distribution was performed with a plane parallel ionization chamber in water, varying the aluminum range-shifter thickness. Ionization electric charges are calibrated with the plane parallel ionization chamber. Figure 2 shows a drawing of the plane parallel ionization chamber used in this study. An electric separation occurs in the ionizing cavity after a proton beam transverses through the incident electrode.

\section{1-2 Calculates of the $E(Z)$-factor}

When the proton beam is first extracted from the accelerator, it is narrow and almost mono-energetic., ${ }^{910)}$ We used a wobbler magnet to expand the beam laterally to a radius of $50 \mathrm{~mm}$ and used two sizes $(15 \mathrm{~mm}$ and $30 \mathrm{~mm}$ ) of ridge filter for the depth. ${ }^{11)}$ Measurement of charged particle distribution within the SOBP was performed with a plane parallel ionization chamber in water for a circular brass collimator of $6 \mathrm{~mm}$ to $20 \mathrm{~mm}$ in diameter as a variation of aluminum range shifter thickness. ${ }^{1,2)}$ Figure 3 shows the SOBP curves for the ratio of average charges as a function of depth in water per range for each range shifter. Ridge filter thickness is $15 \mathrm{~mm}$, and the diameter of the circular collimator is $20 \mathrm{~mm}$.

From the SOBP curves with different thicknesses of range shifters for a square field size of $3 \times 3 \mathrm{~cm}^{2}$ for the $15 \mathrm{~mm}$ thick ridge filter, the gradient of the SOBP

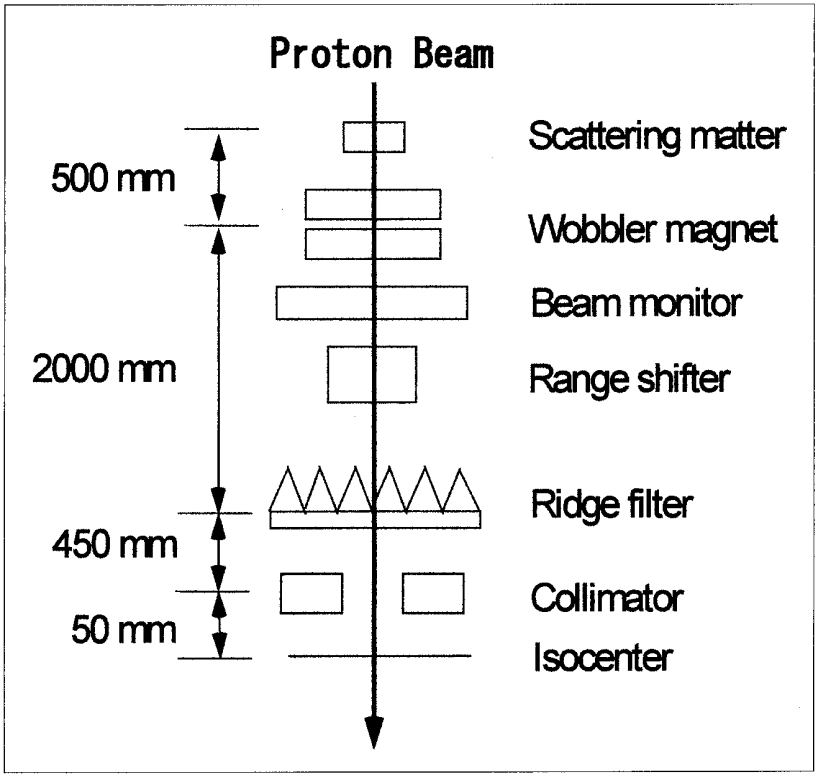

Fig. 1 Drawing of the proton delivery equipment used in this experiment.

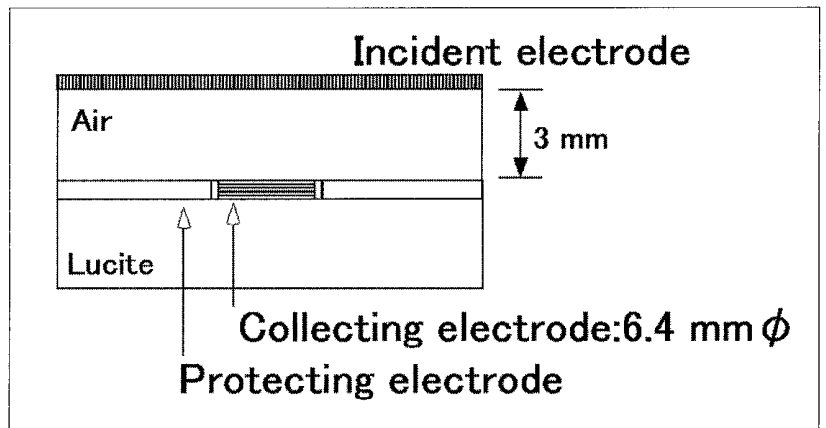

Fig. 2 Drawing of the plane parallel ionization chamber used in this study.

decreases gradually as range shifter thickness increases. ${ }^{3)}$

The value of charged particles at the surface of a water phantom was used as the standard value, and the SOBP distribution was plotted for each range shifter thickness. It was calculated for each depth of the SOBP compared with each charged particle when making the value of the charged particle for the $0 \mathrm{~mm}$ thick range shifter 1.0. The value of a charged particle in the $0 \mathrm{~mm}$ thick range shifter was designated $P_{e q}$, and the value of the other range shifter was designated $P$. The $\mathrm{E}(Z, R)$ factor was calculated as both ratios. This calculation was performed on the assumption that the depth on SOBP in the $0 \mathrm{~mm}$ thick range shifter satisfies longitudinal charged particle equilibrium for the reason that, by not putting range shifter in, it is possible to obtain the range in equilibrium. The range of $70 \mathrm{MeV}$ proton beams in water is $37.81 \mathrm{~mm} .{ }^{12)}$ Similarly, we measured the $\mathrm{E}(Z)$ - 


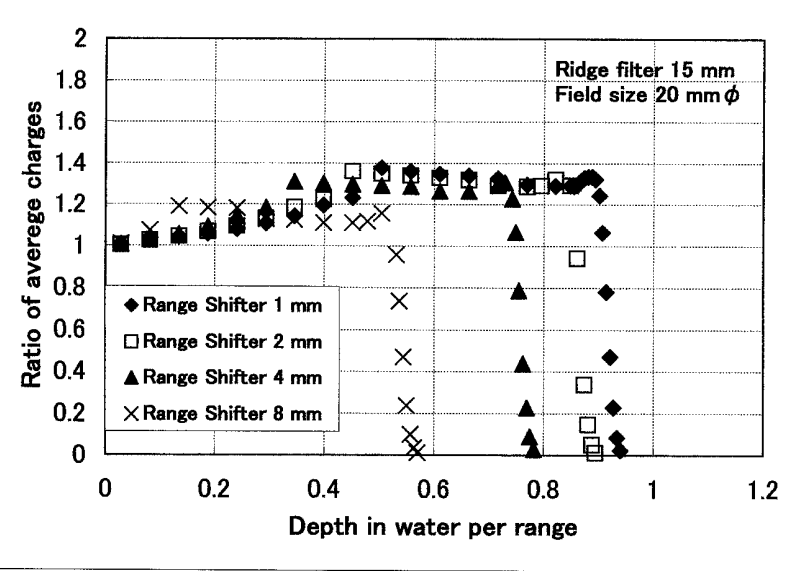

Fig. 3 SOBP curves for the ratio of average charges as a function of depth in water per range for each range shifter. Ridge filter thickness is $15 \mathrm{~mm}$, and diameter of the circular collimator is $20 \mathrm{~mm}$.

factor for the different field sizes.

\section{1-3 Measurements of the $E(R)$-factor}

The plane parallel ionization chamber was positioned pointing vertically toward the primary proton beam for each depth of the SOBP slope. A front of the parallel plate electrode was established as the effective measuring center. Measurement was carried out for different field sizes, which are formed from circular brass collimators with diameter ranging between $6 \mathrm{~mm}$ and $20 \mathrm{~mm}$. The value of a charged particle for field size $20 \mathrm{~mm} \phi$ was designated as 1.0 , where the $\mathrm{E}(R)$-factors were calculated for the values of charged particles for each field size.

\section{1-4 Calculation of the $E(Z)$-factor of primary proton \\ Measurement of the charged particle distribution} within the SOBP was performed for each field size according to variation in range-shifter thickness. To exclude the influence of secondary charged particles from the $\mathrm{E}(Z)$-factor of primary protons, the $\mathrm{E}(Z)$-factor was extrapolated to zero field size at each depth in the SOBP. The value of charged particles for the $0 \mathrm{~mm}$ thick range shifter was designated as 1.0 , where the ratio of charged particles at each depth in the SOBP was calculated. The $\mathrm{E}(Z)$-factor of primary protons was calculated for each range shifter.

\section{Results}

Figure 4 shows the $\mathrm{E}(Z)$-factor curves of $20 \mathrm{~mm} \phi$ field size for the $15 \mathrm{~mm}$ and $30 \mathrm{~mm}$ thick ridge filter.

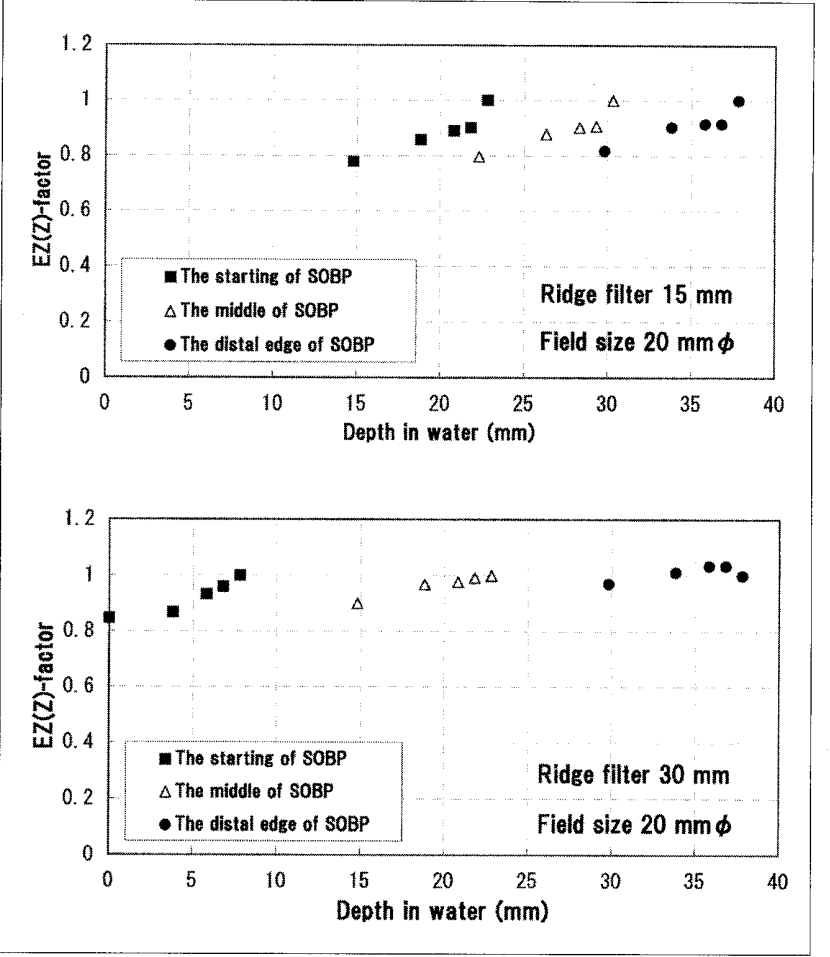

Fig. 4 (a) $E(Z)$-factor curves of $20 \mathrm{~mm} \phi$ field size a for a $15 \mathrm{~mm}$ thick ridge filter.

(b) $E(Z)$-factor curves of $20 \mathrm{~mm} \phi$ field size b for a $30 \mathrm{~mm}$ thick ridge filter.

The horizontal axis of the graph represents the depth in water, and the vertical axis represents the $E(Z)$ factors at each depth in the SOBP.

The horizontal axis of the graph represents depth in water, and the vertical axis represents the $\mathrm{E}(Z)$-factor at each depth in the SOBP. From the graphs, the value of the $\mathrm{E}$ (Z)-factor decreased gradually with the shallow depth in water at each position of the SOBP. The gradient at the start of the SOBP is larger than that at its distal edge. For the ridge filters, the gradient is larger for the $15 \mathrm{~mm}$ thickness. For the effect on field size, the $E(Z)$-factor decreases gradually with the decrease of depth in water, but the difference in values of charged particles at each depth in the SOBP decreases with the decrease in field size.

Figure 5 shows the $\mathrm{E}(R)$-factor curve for the $8 \mathrm{~mm}$ thick range shifter with the $15 \mathrm{~mm}$ thick ridge filter. The horizontal axis of the graph represents the diameter of the circular field size, and the vertical axis represents the $\mathrm{E}(R)$-factor. From the graph, the $\mathrm{E}(R)$-factor decreases sharply with the decrease of field size to $10 \mathrm{~mm} \phi$; the value of the $\mathrm{E}(R)$-factor is independent of the depth in SOBP. From the result, it was suggested that the lateral components of charged particles were in equilibrium for field sizes up to $10 \mathrm{~mm} \phi$. From there, we ex- 


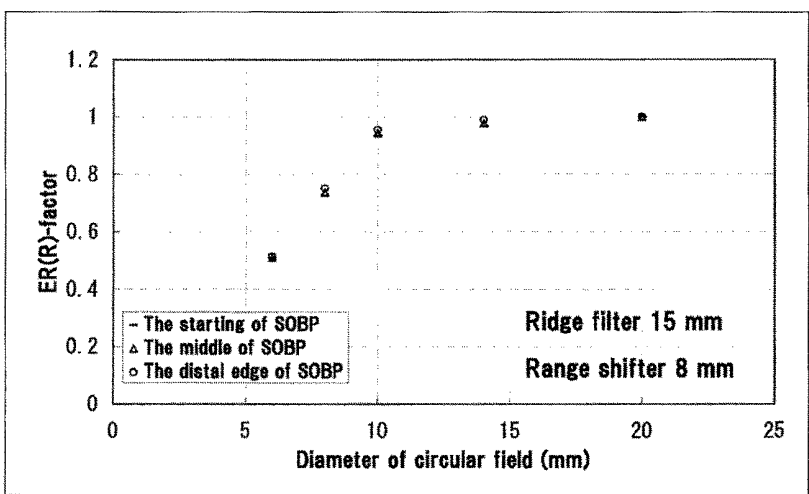

Fig. 5 The $E(R)$-factor curve for the $8 \mathrm{~mm}$ thick range shifter with the $15 \mathrm{~mm}$ thick ridge filter. The horizontal axis of the graph represents the diameter of circular field size, and the vertical axis represents the $E(R)$-factor.

trapolated the $\mathrm{E}(R)$-factor to zero field size for field sizes between $10 \mathrm{~mm} \phi$ and $20 \mathrm{~mm} \phi$. Taking the value of the $\mathrm{E}(R)$-factor for a $0 \mathrm{~mm}$ thick range shifter as 1.0 , we calculated the $\mathrm{E}(Z)$-factor of the primary proton.

Figure 6 shows the $\mathrm{E}(Z)$-factors for the zero field sizes of the 15 and $30 \mathrm{~mm}$ thick ridge filters. The horizontal axis represents the depth in water, and the vertical axis represents the $\mathrm{E}(Z)$-factor of zero field size at each depth in the SOBP. From the results, the $E(Z)$-factor for zero fields at each depth is almost the same; the difference in the value of the $\mathrm{E}(Z)$-factor for zero field for the $8 \mathrm{~mm}$ thick range shifter is small. The $\mathrm{E}(Z)$-factors at each depth in the SOBP are almost the same.

\section{Discussion}

For the longitudinal components, the $\mathrm{E}(Z)$-factor decreases gradually with shallow depth in water, and the gradient at the start of SOBP was the largest. It was indicated that charged particle equilibrium at a longitudinal component is not formed in the shallow depth in water. This is due to the distance between the detector and range shifter, and it is an important factor. In the case of a $0 \mathrm{~mm}$ thick range shifter, the primary proton beam is attenuated only by water, and that is designated as the standard value for calculation of the $E(Z)$-factor, but the rate of attenuation for the range shifter increases with shallow depth in water. Longitudinal components of secondary charged particles generated from a $0 \mathrm{~mm}$ thick range shifter are in equilibrium. This is because secondary charged particles generated from aluminum cannot penetrate the detector; therefore the $\mathrm{E}(Z)$-factor is not affected by these particles. The lon-
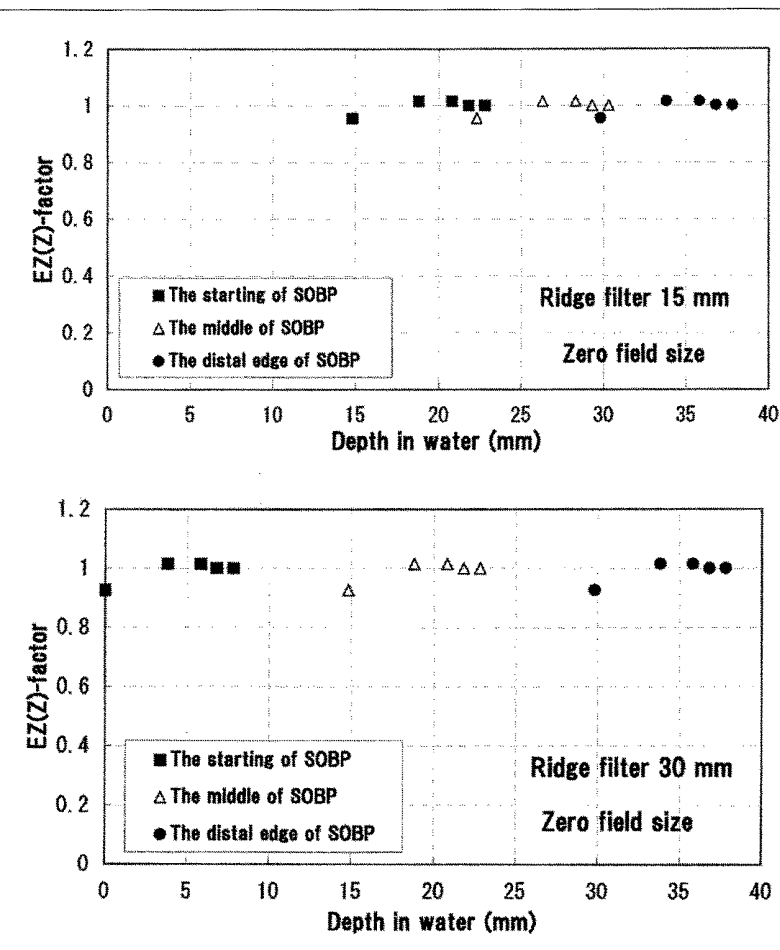

Fig. 6 (a) The $E(Z)$-factor for the zero field size a of the $15 \mathrm{~mm}$ thick ridge filter.

(b) The $E(Z)$-factor for the zero field size b of the $30 \mathrm{~mm}$ thick ridge filter.

The horizontal axis represents the depth in water, and the vertical axis represents the $E(Z)$-factor of zero field size at each depth in the SOBP.

gitudinal components of secondary charged particles at shallow depth in the SOBP are not in equilibrium. Hence the absorbed dose is reduced by the lack of these components. There are many secondary charged particles at the distal edge of the SOBP in water, since the depth in water for the distal edge of the SOBP is deeper than the depth for the starting of the SOBP. The dose distribution is influential by a decrease of absorbed dose with failure of charged particle equilibrium in the longitudinal component as well as a decline of the therapeutic effect. The gradient of the $\mathrm{E}(Z)$-factor for the $15 \mathrm{~mm}$ thick ridge filter is larger than the $30 \mathrm{~mm}$ thick ridge filter. This is due to the differences in height and the number of ridges in the ridge filter. The number of ridges in the $15 \mathrm{~mm}$ thick ridge filter is less, and the height of the $15 \mathrm{~mm}$ thick ridge filter is shorter than that of the $30 \mathrm{~mm}$ thick ridge filter. Therefore, a secondary charged particle that passes through the section along a slope of the ridge filter increases and the difference in value of each range shifter increases. Consequently, charged particle equilibrium is affected by secondary charged 
particles generated from the ridge filter.

The $\mathrm{E}(\boldsymbol{R})$-factor decreases with decreasing field size up to $10 \mathrm{~mm} \phi$. It was indicated that charged particle equilibrium in the lateral component is not formed below field size $10 \mathrm{~mm} \phi$. This is due to the range of the secondary charged particles. As a result of lateral charged particle equilibrium, the range of the secondary charged particle is longer than the size of the small field. To determine the $\mathrm{E}(Z)$-factor of primary protons, measurement must be performed for different field sizes, and all field sizes must be large enough for lateral charged particle equilibrium. For field sizes between $10 \mathrm{~mm} \phi$ and $20 \mathrm{~mm} \phi$, it is useful that the $\mathrm{E}(R)$-factor is extrapolated to zero field size.

In Fig. 6, the $\mathrm{E}(Z)$-factors for zero field size at each depth are almost the same. These values are the $\mathrm{E}(Z)$ factors of primary protons. The $\mathrm{E}(Z)$-factor was approximately 1.0 in shallow depth near the surface of the water phantom in Fig. 6(b). This territory was equivalent to the start of SOBP. As a result, we suggested that the longitudinal component of primary protons is in equilibrium at each depth. From the result, the $\mathrm{E}(Z)$-factor at each depth of the SOBP is much the same, and the charged particle equilibrium in primary protons is independent of the shift of SOBP. The reason is that protons are direct charged particles. The $\mathrm{E}(Z)$-factor of primary protons at each depth of SOBP shifted by the 8 mm thick range shifter is small. This is due to the quality of the proton beam. The attenuation of the primary proton beam by aluminum before penetrating through water increases with increasing range shifter thickness and therefore changes beam quality.

\section{Conclusions}

In this study, we measured the charged particle equilibrium factor of $70 \mathrm{MeV}$ proton beams and established the relation between proton beam quality and secondary charged particles. At shallow depth, the longitudinal component of primary protons is in equilibrium. The charged particle equilibrium factor decreases at shallow depths and for small fields. This is because charged particle equilibrium is affected by secondary charged particles.

It is suggested that the absolute dose is affected by the secondary charged particles generated from the different configurations of the ridge filter's thickness and range shifter's position. Varying proton beam quality means that the primary beam profile changes with the two effects and are not independent. It is as expected that the energy of the secondary charged particles is affected by the quality of the primary proton beam. The accuracy of separation of the effects of proton beams and secondary charged particles depends on the accuracy of the expression used to describe the equilibrium dose at the shallow depth and small field. The conclusions of this study are likely to be most important for measuring and extrapolation the absorbed dose, and for testing beam quality before they are taken into clinical use.

\section{Acknowledgments}

The detailed data provided for the clinically modulated $70 \mathrm{MeV}$ proton beam from NIRS are gratefully acknowledged. We would like to thank Dr. Takeshi Hiraoka of NIRS and Dr. Toraji Irifune of Tokyo Metropolitan University of Health Sciences.

\section{References}

1) Kawachi K, Kanai T, Matsuzawa H, et al.: Proton radiotherapy facility using a spot scanning method. Nippon Acta Radiologica, 42, 467-475, (1982).

2) Hiraoka T, Kawashima K, Hoshino K, et al.: Dose distributions for proton spot scanning beams: effect by range modulators. Nippon Acta Radiologica, 43, 1214-1223, (1983).

3) Ohtani H, Irifune T, Hiraoka T, et al.: Study of the Physical Characteristics and the Dose Evaluation of Clinical Proton Beams - The Effect of Range Shifter Thickness on the Slope of Spread-Out-Bragg-Peak (SOBP). Bulletin of Tokyo Metropolitan College of Allied Medical Sciences, 10, 9-16,(1998).

4) Ceberg CP, Bjarngard BE, and Zhu TC: Experimental determination of the dose kernel in high-energy x-ray beams. Med Phys, 23, 505-511, (1996).

5) Bjarngard BE, and Shackford $\mathrm{H}$ : Attenuation in high-energy x-ray beams. Med Phys, 21, 1069-1073,(1994).

6) Bjarngard BE, Vadash P, and Zhu T: Doses near the surface in high-energy x-ray beams. Med Phys, 22, 465-468, (1995).

7) Medin J, and Andreo P: Monte Carlo calculated stoppingpower ratios, water/air, for clinical proton dosimetry $(50-250$ MeV). Phys Med Biol, 42, 89-105, (1997).

8) Arduini G, Cambria R, Canzi C, et al.: Physical specifications of clinical proton beams from a synchrotron. Med Phys, 23, 939-951, (1996).

9) Larsson B: Radiological properties of beams of high-energy protons. Radiat Res Suppl, 7, 304-311,(1967).

10) Graffman S, Jung B, Nohrman B, et al.: Supplementary treatment of nasopharyngeal tumours with high energy protons. Acta Radiol Ther Phys Biol, 6, 361-368, (1967).

11) Kanai T, Kawachi K, Kumamoto $Y$, et al.: Spot scanning system for proton radiotherapy. Med Phys, 7, 365-369, (1980).

12) ICRU Report 49: Stopping Powers and Ranges for Protons and Alpha Particles. 107-181,(1993). 


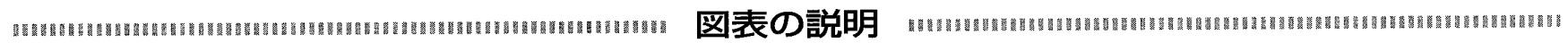

Fig. 1 研究に使用した医用陽子線システム

Fig. 2 研究に使用した平行平板形電離箱の構造図

Fig. 3 水中における飛程を基準とした電離電荷比から算出した各レンジシフターにおける拡大ブラッグピーク曲線. リッジフィ ルター厚は $15 \mathrm{~mm}$ ，照射野直径は $20 \mathrm{~mm}$.

Fig. 4 (a)リッジフィルター15mm厚における照射野 $20 \mathrm{~mm} \phi$ のE $(Z)$-factor曲線

(b)リッジフィルター30 mm厚における照射野 $20 \mathrm{~mm} \phi$ の $(Z)$-factor曲線

横軸は水中での梁さ, 縦軸は拡大ブラッグピークの各位置での零照射野のE $(\mathrm{Z})$-factorを示す.

Fig. 5 リッジフィルター $15 \mathrm{~mm}$ 厚におけるレンジシフター $8 \mathrm{~mm}$ 厚のE $(R)$-factor曲線 横軸は円形照射野の直径, 縦軸はE $(R)$-factorを示す.

Fig. 6 (a)リッジフィルター $15 \mathrm{~mm}$ 厚における零照射野の $\mathrm{E}(Z)$-factor曲線

(b)リッジフィルター30mm厚に扔ける零照射野のE $(Z)$-factor曲線

横軸は水中での深さ，縦軸は拡大ブラッグピークの各位置での零照射野のE $(Z)$-factorを示す. 